\title{
Intraoperative thermal coronary angiography - correlation between internal mammary artery (IMA) free flow and thermographic measurement during coronary grafting
}

\author{
by M. Kaczmarek ${ }^{1}$, A. Nowakowski ${ }^{1}$, J. Siebert ${ }^{2}$ and J. Rogowski ${ }^{2}$ \\ ${ }^{7}$ Department of Medical and Ecological Electronics, Technical University of Gdańsk, Gdańsk, Poland; \\ e-mail: mariusz@biomed.eti.pg.gda.pl \\ ${ }^{2}$ Cardiac Surgery Department, Medical University of Gdańsk, Gdańsk, Poland
}

\begin{abstract}
In this paper the intraoperative thermoangiographic evaluation of the patency and flow in the internal mammary artery (IMA) anastomosed to the anterior descending branch of the left coronary artery (LAD) is presented.

30 patients were operated due to ischemic heart disease, using cardiopulmonary bypass technique. LIMA was anastomosed to the left anterior descending (LAD) branch in all cases, additional venous grafts were applied in 29 cases. Thermographic evaluation was performed in the rewarming phase of the operation, when all grafts were anastomosed to coronary arteries. After the peripheral coronary anastomoses are completed, IMA clamp is released. The inflow of warm blood into the previously cooled area creates appropriate temperature gradient for thermographic recording. This warranted very good imaging quality of the heart and coronary arteries. Even small branches could be visualised using this system.
\end{abstract}

\section{Method}

The aim of our study is the intraoperative thermoangiographic evaluation of the patency and flow in the internal mammary artery (IMA) anastomosed to the anterior descending branch of the left coronary artery (LAD). Mathematical modelling of the phenomena can be useful for automatic recognition in real time procedures.

Agema Thermovision 900 SW/TE with 200 lens, using an electronically cooled (Peltier's effects) detectors, the spectral range $2.5-5.4 \mu \mathrm{m}$, and resolutions: spatial -2.5 mradian and thermal $0.1{ }^{\circ} \mathrm{C}$ was used. The measurement temperature range from -100 to $80^{\circ} \mathrm{C}$ with subranges of $10^{\circ} \mathrm{C}$ adjusted by an operator to the expected temperatures was used. The camera was mounted on a separate arm over the patient at the distance of 1.2 meter and focused directly on the exposed surface of the heart. The images were displayed in the iron scale with 256 colour levels. The selected sequences from each patient study were stored on a hard disk.

30 patients were operated due to ischemic heart disease, using cardiopulmonary bypass (CPB) technique. Left Internal Mammary Artery (LIMA) was anastomosed to the Left Anterior Descending (LAD) branch in all cases, additional 59 venous grafts were applied in 29 cases. LIMA was harvested before starting CPB and a 30-second free flow was checked in each case to monitor the flow of blood and to estimate a quality of LIMA.

After the peripheral coronary anastomoses are completed, IMA clamp is released. The inflow of warm blood into the previously cooled area creates appropriate temperature gradient for thermographic recording. This warranted very good imaging quality of the heart and coronary arteries. Even small branches could be visualised using this system.

Digital processing of the images enhanced their quality and made possible more accurate analysis of the graft and coronary artery patency. Sequential image analysis allowed to estimate the temperature profiles of specific areas in different time intervals, which was an important factor of early IMA - LAD graft flow detection. This showed the direction of 
LIMA and LAD flow, the anastomosis size and patency. Good flow was recorded in 29 cases, restricted flow in one case.

\section{Analysis and results}

Computerized image analysis provided the option of storing single frames at given time intervals, allowing comparison of subsequent image sequences. This enables us to compare the flow dynamics of different grafts with respect to inflow characteristics.

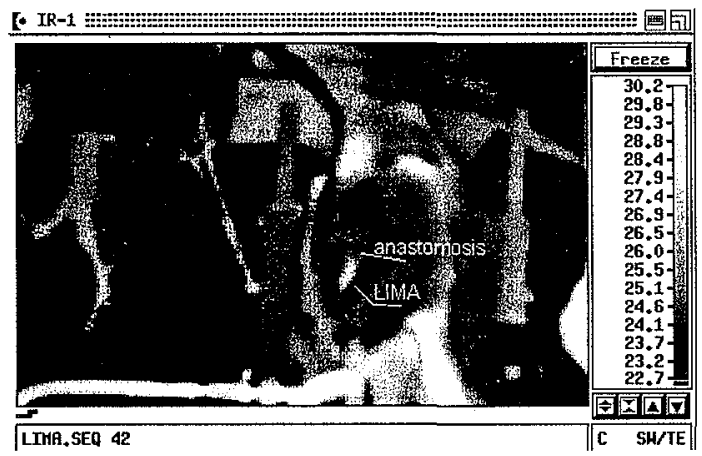

Fig. 2a. Intraoperative detection of impaired function of LIMA - LAD. Abnormal flow in LIMA and its anastomosis to LAD does not fill distal parts of LAD (recorded 5 seconds after clamp release).

In our study only one patient for 30 operations was with poor flow through LIMA-LAD graft. There was no anterograde filling of the $L A D$, only a diagonal branch was perfused retrogradely. In this case additional vein graft was performed. It is show on the figures below.

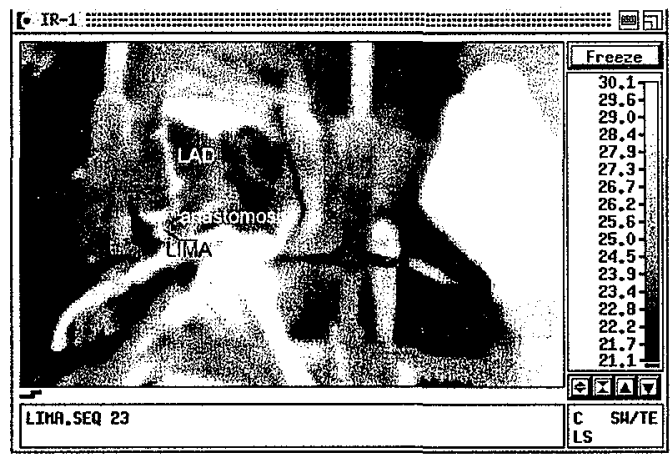

Fig. 1a. Patient with proximal narrowing in LAD and normal function of LIMA-LAD graft. Intraoperative thermoangiography (TAG) shows good connection and blood flow through LIMA-LAD anastomosis. This site, filled with warm blood is coloured light. Cold heart muscle is dark. Picture is taken 5 seconds after LIMA clamp release. 


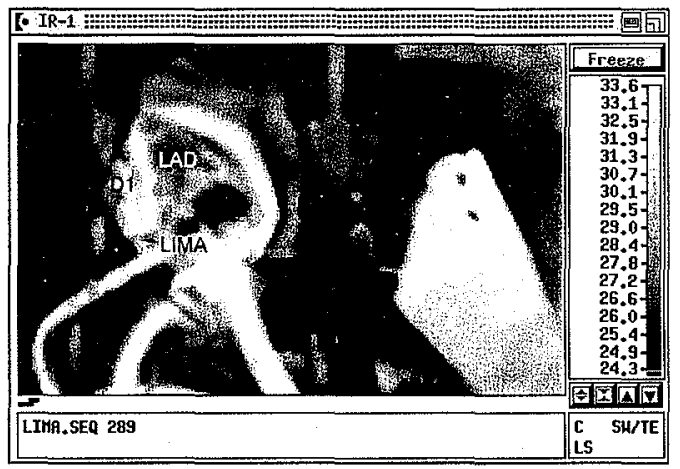

Fig. 1b. The heart muscle 60 seconds later shows further filling of LAD with warm blood, also in proximal direction. Warmth propagation in more distal segments is evident.

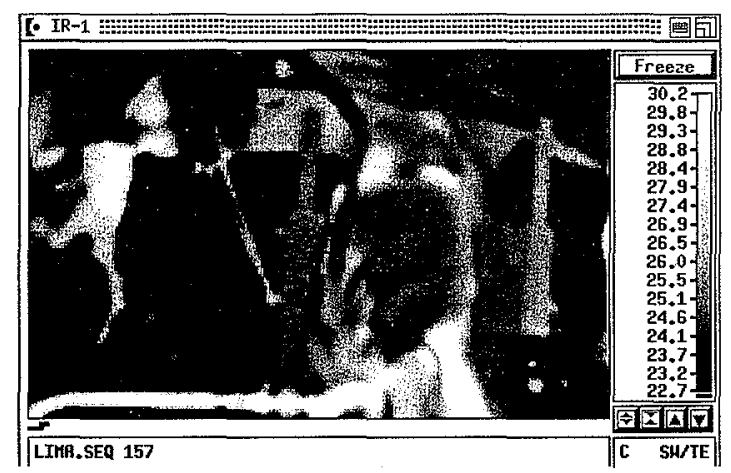

Fig. 2b. After 60 seconds; warm blood inflow is absent. There is no anterograde filling of the LAD only diagonal branch $D 1$ is perfused retrogradely.

We found the correlation between LIMA free flow and thermographic measurements. In Tables 1 and 2 one can see temperature increment for two different values of free flow from LIMA. The data in the table is corresponding to the pictures shown before - respectively Table 1 to Fig. 1; Table 2 to Fig. 2.

Temperature is taken from two points: $\mathrm{Sp} 1$ - before anastomosis (LIMA) and $\mathrm{Sp} 2$ after anastomosis (LAD). Temperature increment is calculated using the formula (1) where $t(0 s)$ - is the time of clamp release from LIMA - start of graft perfusion.

$$
\Delta t(x s)=t(x s)-t(0 s) ;\left[{ }^{0} \mathrm{C}\right]
$$

Table 1. Free flow from LIMA-120 $\mathrm{ml} / \mathrm{min}$

\begin{tabular}{|c|c|c|c|c|}
\hline $\begin{array}{c}\text { Time } \\
{[\mathrm{sec}]}\end{array}$ & $\begin{array}{c}\mathrm{T} \text { in Sp1 } \\
{\left[{ }^{0} \mathrm{C}\right]}\end{array}$ & $\begin{array}{c}\mathrm{T} \text { in Sp2 } \\
{\left[{ }^{0} \mathrm{C}\right]}\end{array}$ & $\begin{array}{c}\Delta \mathrm{T} \text { in Sp1 } \\
{\left[{ }^{0} \mathrm{C}\right]}\end{array}$ & $\begin{array}{c}\Delta \mathrm{T} \text { in Sp2 } \\
{\left[{ }^{0} \mathrm{C}\right]}\end{array}$ \\
\hline 0 & 28.2 & 25.6 & 0 & 0 \\
\hline 1 & 28.4 & 25.8 & 0.2 & 0.2 \\
\hline 5 & 29.5 & 27.8 & 1.3 & 1.7 \\
\hline 10 & 30.1 & 28.2 & 1.9 & 2.7 \\
\hline 15 & 30.8 & 28.9 & 2.6 & 3.3 \\
\hline 20 & 31.5 & 29.5 & 3.4 & 3.9 \\
\hline 25 & 31.5 & 30.1 & 3.3 & 4.5 \\
\hline 30 & 31.6 & 30.6 & 3.4 & 5.1 \\
\hline
\end{tabular}

Table 2. Free flow from LIMA $=40 \mathrm{ml} / \mathrm{min}$

\begin{tabular}{|c|c|c|c|c|}
\hline $\begin{array}{c}\text { Time } \\
\text { sec] }]\end{array}$ & $\begin{array}{c}\mathrm{T} \text { in Sp1 } \\
{\left[{ }^{\circ} \mathrm{C}\right]}\end{array}$ & $\begin{array}{c}\mathrm{T} \text { in Sp2 } \\
{\left[{ }^{\circ} \mathrm{C}\right]}\end{array}$ & $\begin{array}{c}\Delta \mathrm{T} \mathrm{in} \mathrm{Sp1} \\
\left.{ }^{\circ} \mathrm{C}\right]\end{array}$ & $\begin{array}{c}\Delta \mathrm{T} \text { in Sp2 } \\
{\left[{ }^{\circ} \mathrm{C}\right]}\end{array}$ \\
\hline 0 & 25.3 & 22.6 & 0 & 0 \\
\hline 1 & 25.7 & 22.7 & 0.4 & 0.1 \\
\hline 5 & 25.4 & 22.7 & 0.1 & 0.1 \\
\hline 10 & 25.6 & 22.7 & 0.3 & 0.1 \\
\hline 15 & 28.1 & 22.8 & 2.8 & 0.2 \\
\hline 20 & 28.7 & 23.4 & 3.4 & 0.8 \\
\hline 25 & 29.2 & 24.1 & 3.9 & 1.5 \\
\hline
\end{tabular}


http://dx.doi.org/10.21611/qirt.1998.040

Temperature increments in LIMA-LAD graft

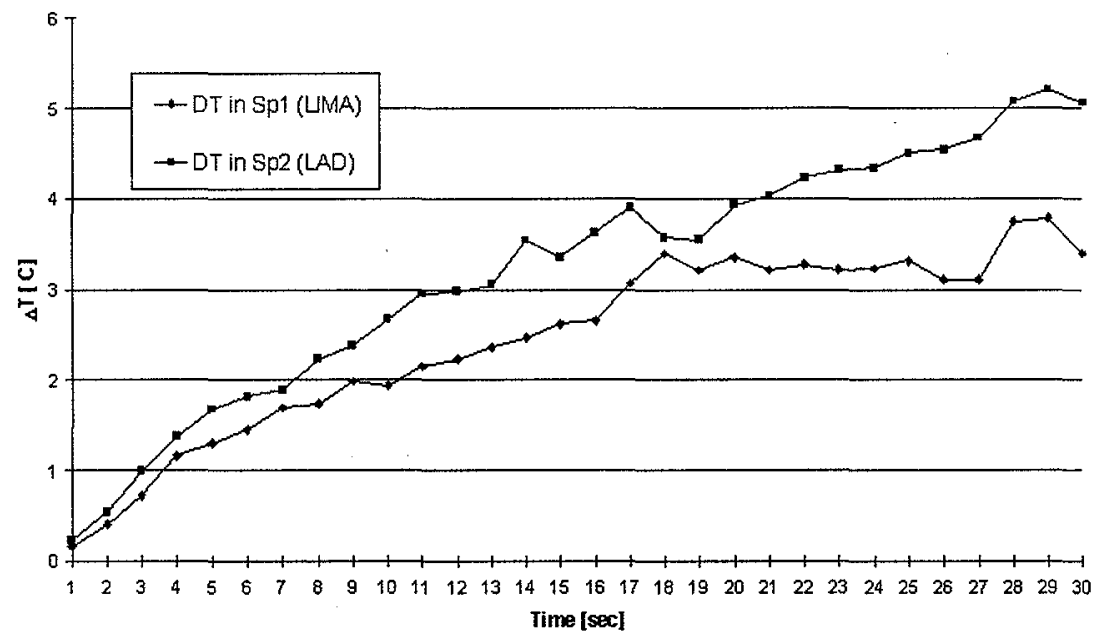

Fig. 3. Temperature increments in LIMA-LAD graft - free flow $=120 \mathrm{ml} / \mathrm{min}$

Temperature increments in LIMA-LAD graft

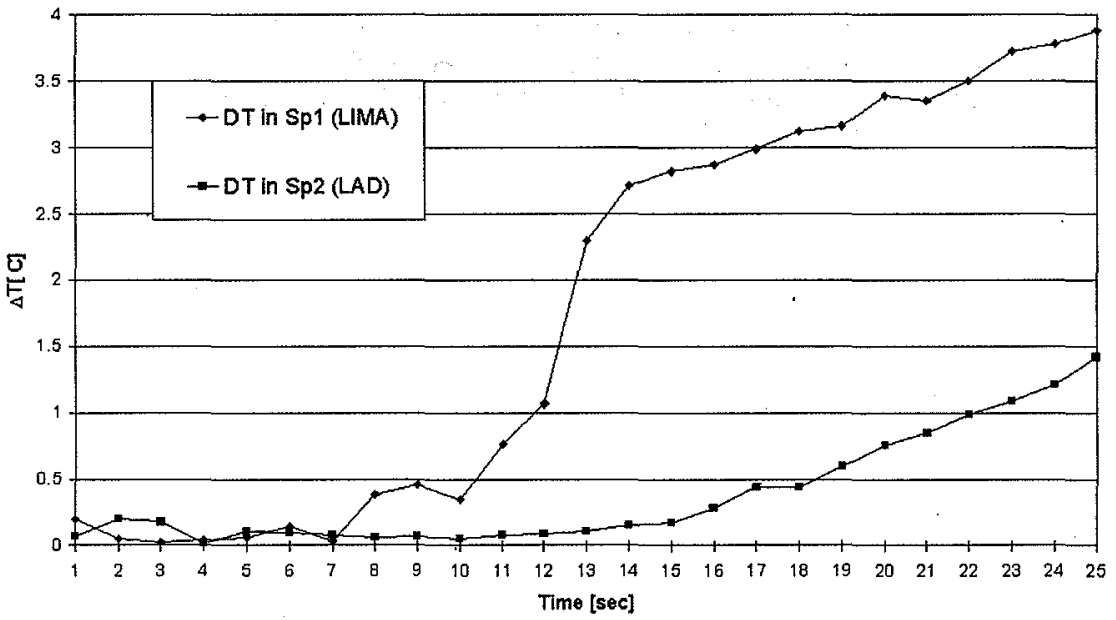

Fig. 4. Temperature increments in LIMA-LAD graft - free flow $=40 \mathrm{ml} / \mathrm{min}$ Mathematical model of heat transfer in the LIMA-LAD graft is:

$$
T(t)=T_{b}-\left(T_{b}-T_{0}\right) \cdot e^{-A(v) t}
$$

where:

$T(t)$ - estimated temperature,

$T_{b}$ - warm blood temperature,

$T_{0}$ - temperature of cold epicardium,

$A(v)$ - coefficient which varies with flow velocity $-v$ 
The result of fitting the mathematical model to the data for two presented before cases is shown below. The continuous line shows the model estimated temperature and the points are the measured data.

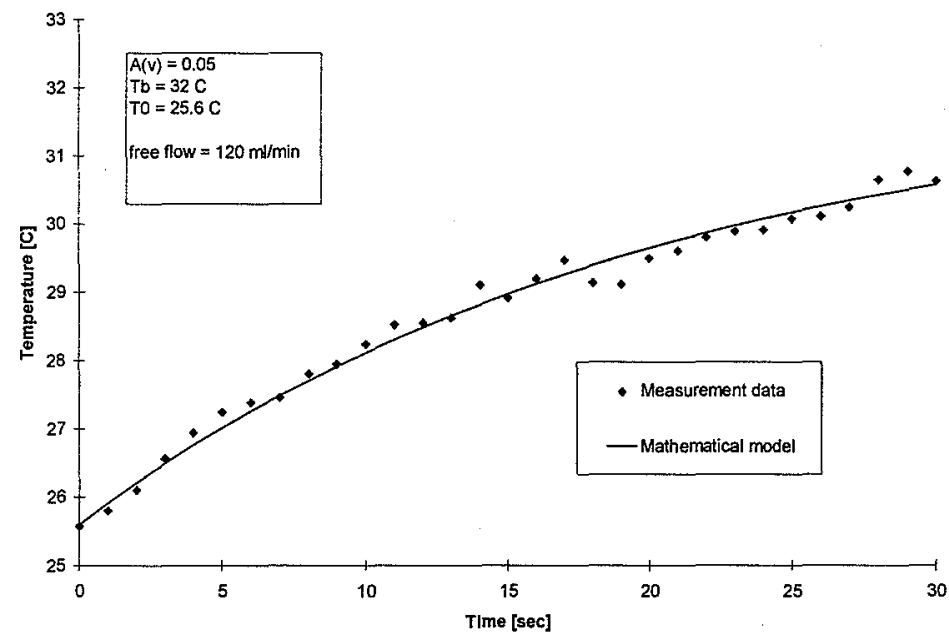

Fig. 5. Mathematical model of heat transfer and measurements data - free flow $=120 \mathrm{ml} / \mathrm{min}$

The relationship between the estimated $A(v)$ coefficient and LIMA free flow calculated for nine patients is presented on the chart below. For good free flow (more than $100 \mathrm{ml} / \mathrm{min}$ ) the value of $A(v)$ coefficient is larger than 0.04 . Correlation between this coefficient and a value of free flow is calculated as $r=0.833$.

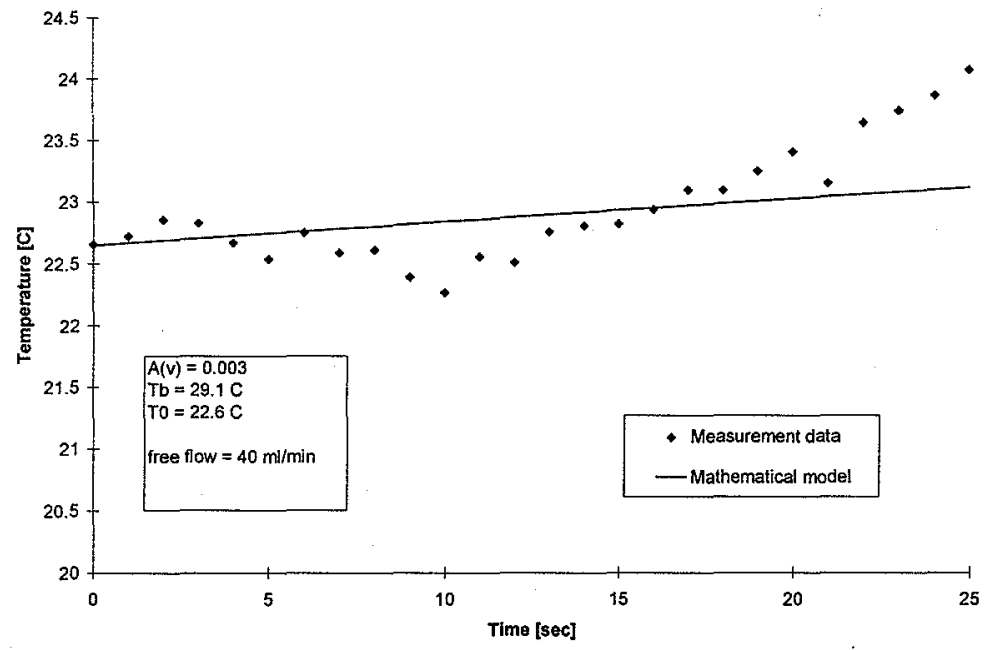

Fig. 6. Mathematical model of heat transfer and measurements data - free flow $=\mathbf{4 0} \mathrm{ml} / \mathrm{min}$ 
http://dx.doi.org/10.21611/qirt.1998.040

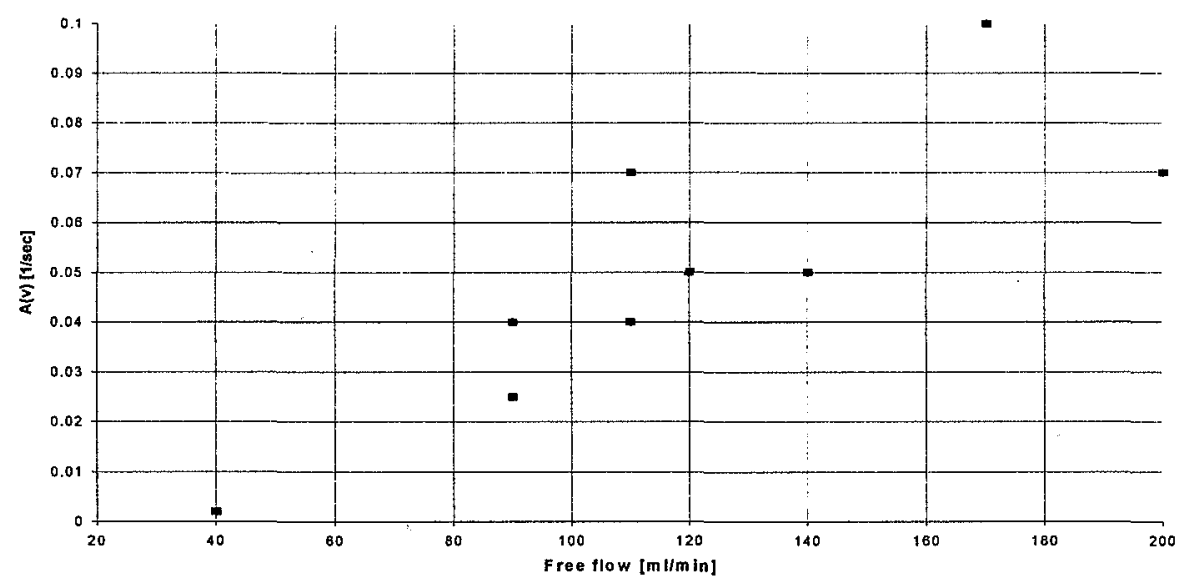

Fig. 7. Relation between $A(v)$ coefficient and free flow values

\section{Conclusion}

Intraoperative thermography can be an useful tool for early detection of a narrow anastomosis or other reason of coronary graft flow restriction. In a case of operation fault the thermographic graft flow evaluation can improve the results of CABG procedures. It is very important that it is real time procedure. One can analyse the sequence of images during CABG surgery, no special equipment is needed.

\section{REFERENCES}

[1] KACZMAREK (M.), NOWAKOWSKI (A.), SIEBERT (J.), ROGOWSKI (J.), "Thermography in intraoperation monitoring of the heart", 42 Internationales Wissenschaftliches Kolloquium - IImenau, Vol. III, pp. 289-291, 1997.

[2] KACZMAREK (M.), SIEBERT (J.), ROGOWSKI (J.), ANISIMOWICZ (L.), LIPSKI (A.), BRZEZIŃSKI (M.), "Termoangiografia śródoperacyjna - ocena przepływu w tętnicy piersiowej wewnętrznej w trakcie operacji przęsłowania naczyń wieńcowych.", I Międzynarodowy Kongres Polskiego Towarzystwa Kardiologicznego, Warszawa, Kardiologia Polska, Vol. XLVII, supl. I, p.156, 1997

[3] JONES (E.L.), LATOUF (O.M.), WEINTRAUB (W.S.), Catastrophic consequences of internal mammary hypoperfusion., Jour. Thorac. Cardiovasc. Surg. 98, p. 202, 1989,

[4] MOHR (F.W.), FALK (V.), KRIEGER (H.), LIKUNGU (J.), ABU AISHA (N.), COPPOLA (R.), DIEGELER (A.), MATLOFF (J.), KIRCHHOFF (P.G.), IMA-graft patency control by thermal coronary angiography during coronary bypass surgery, Eur. J. Cardiothorac. Surg. 5 pp. 534-541, 1991

[5] MOHR (F.W.), FALK (V.), PHILIPPI (A.), AUTSCHBACH (R.), KRIEGER (H.), DIEGELER (A.), DALICHAU (H.), Intraoperative assessment of internal mammary artery bypass graft patency by thermal coronary angiography. Cardiovasc-Surg. 1994 Dec; 2(6), pp. 703-710, 1994 